\title{
SEISMIC PERFORMANCE OF RC FLAT SLAB STRUCTURE WITH DIFFERENT TYPES OF STEEL BRACING
}

\author{
Dakshayani $\mathbf{S}^{1}$, Chaithra $\mathbf{N}^{2}$ \\ ${ }^{1}$ MTech, Department of Civil Engineering, Global Academy of Technology, Bengaluru-560098 \\ ${ }^{2}$ Assistant Professor, Department of Civil Engineering, Global Academy of Technology, Bengaluru-560098
}

\begin{abstract}
One of the lateral load opposing frameworks in multi-storey structures is Steel brace frame. The resistance of the structure which enhances against horizontal forces by expanding its stiffness and stability is Steel bracing system in RC multi-storey building is conservative, simple to set up, involve less space and give obliged quality and inflexibility. $X, K$, inverted $V$, and Diagonal and knee bracings are distinct types of bracing systems. Flat slab reinforced buildings have exhibit many dominance over conventional type of beam column building. However, the effectiveness of structure in flat slab construction is inferior in performance under earthquake loading. Flat slab requires the simple formwork which usually result in an economical construction. In present study, a G+9 storey building is analysed for seismic zone IV as per IS 1893: 2002 using ETABS software. The effectiveness of various types of steel bracing (ISMB 450) i.e. X, $V$, inverted $V$, diagonal bracing are examined. Flat slab is also used by providing drop panels and peripheral beam. For all models parameters are kept constant. The effect of the distribution of the steel bracing along the flat slab to RC frame on the seismic performance of the building is studied. The performance of the building is evaluated in terms of storey displacement, storey shear, story drifts and slab stresses. The percentage reduction in lateral displacement along $X$ direction is tabulated. As compared to $V$ and diagonal braced frame, the inverted Vand X braced frame reduces the displacements and storey drift of the structure when combined with flat slab. The storey shear is significantly more for $V$ and inverted $V$ bracing. Providing the steel bracings and Flat slab with drop panels gives less slab stress on structure compared to RC bare frame. Hence it is concluded that the use of steel bracing with flat slab in construction resists the lateral forces for many vulnerable conditions.
\end{abstract}

Keywords: Steel Bracings, Flat Slab, Peripheral Beam, Drop Panel, Seismic Zone, Response Spectrum Analysis

\section{INTRODUCTION}

Earthquake is one of the most destructive natural calamities. It is termed as abrupt and transient motion of the earth's crust, which originates below the surface of earth naturally. Earthquakes are caused due to the movement of the tectonic plates which are interconnected to each other, both in direction and magnitude, leads to an accumulation of strain, both at the plate boundaries and inside the plates.

At the plate or at the fault's boundaries due to slips most earthquakes are produced. There are many records which show that the results which destroys many properties and loss of human lives which finally affects the national economy due to occurrence of earthquakes.

The land for housing demand is increasing due to increased population periodically. The only option is multi-storey buildings to fulfil the need of the land for housing and development of commercial offices.

The multi-storey buildings are highly susceptible to additional lateral loads due to earthquake and wind hence this type of development requires safety. The necessity of the introduction of special measures to decrease the deformations in which multi-storey RC buildings undergoes excessive deformation.

\subsection{Steel Brace and Flat Slab}

For multi storey reinforced concrete these are the frequently used for hotels, hospitals, apartment houses and dormitories. In Flat slab the drawback is their lateral load resistance hence special features like steel brace can be provided for High rise constructions.

- One of the lateral load opposing frameworks in multistorey structures is Steel brace frame. The resistance of the structure which enhances against horizontal forces by expanding its stiffness and stability is Steel bracing system.

For example, by interchanging the horizontal loads the steel bracings hold the structure stable from wind or quake from the opposite side and ground loads. Steel bracing members in RC multi-storey building is conservative, simple to set up, involve less space and give obliged quality and inflexibility. $\mathrm{X}, \mathrm{K}$, inverted $\mathrm{V}$, and Diagonal and knee bracings are distinct types of bracing systems.

- Flat slab can also be used by providing drop panels. Usually column patterns are on a rectangular grid and peripheral beam can be added. In flat slab structures the supporting columns loads are directly considered. Flat slab requires the simple formwork which usually result in an economical construction. 


\subsection{Need for Present Study}

- $\quad$ From the first high rise buildings constructed in the old century until the modern days, the structure has played a major role in the overall design.

- The structural engineers focus to increase the height and slenderness which brought a change from static gravity loads to horizontal dynamic loads generated by wind and earthquakes.

- There was necessary to develop the different kind of structural system, in that by incorporating steel braces and flat slab in the structures is one such method came into existence.

- Several previous studies show that the use of bracing in a building is highly efficient and economical method to resist lateral forces.

- The use of flat slab in construction of building has many advantages but it is not suitable for supporting brittle (masonry) portions.

- Use of drop panels reduces deflection by stiffening the flat slab from which slab stresses get reduced.

- To overcome some of the disadvantages of above point both bracing systems and flat slabs (with and without drop) has been combined in our present study.

\subsection{Objective of the Study}

- To compare the behavior of Framed RC structure with flat slab structure with drop panel and flat slab structure without drop panel.

- To study the performance level of flat slab structure when added with the steel bracing using linear dynamic analysis (response spectra method).

- To study the behavior different bracing systems (i.e. X, $\mathrm{V}$, Diagonal and inverted $\mathrm{V}$ bracings)

- To understand the behavior of FSWP (Flat Slab with Perimeter beam) with drop panel and with different bracings systems.

- To obtain the most effective bracing which resist the lateral loads among all the bracings considered.

- To study the results of lateral displacement, shear storey, storey drift and slab stresses of a flat slab structure assigned with steel bracing.

- To identify the most vulnerable building among the models considered for seismic action.

\section{BUILDING DESCRIPTION}

In this study four different types of bracing has been chosen i.e. $\mathrm{X}, \mathrm{V}$, inverted $\mathrm{V}$, diagonal in the structure. The plan, floor to floor height, column size, peripheral beam, flat slab thickness, floor finish loads, wall loads, live loads and Response-spectra data remains same for all the models.

The models consists of $\mathrm{G}+9$ stories in which column spacing is 5malong both directions. For all models the column of size $900 \times 900 \mathrm{~mm}$, peripheral beam of $500 \times 500 \mathrm{~mm}$ and steel bracing (ISMB 450) is kept constant. The Response Spectrum analysis is made for all the buildings using ETABS software.

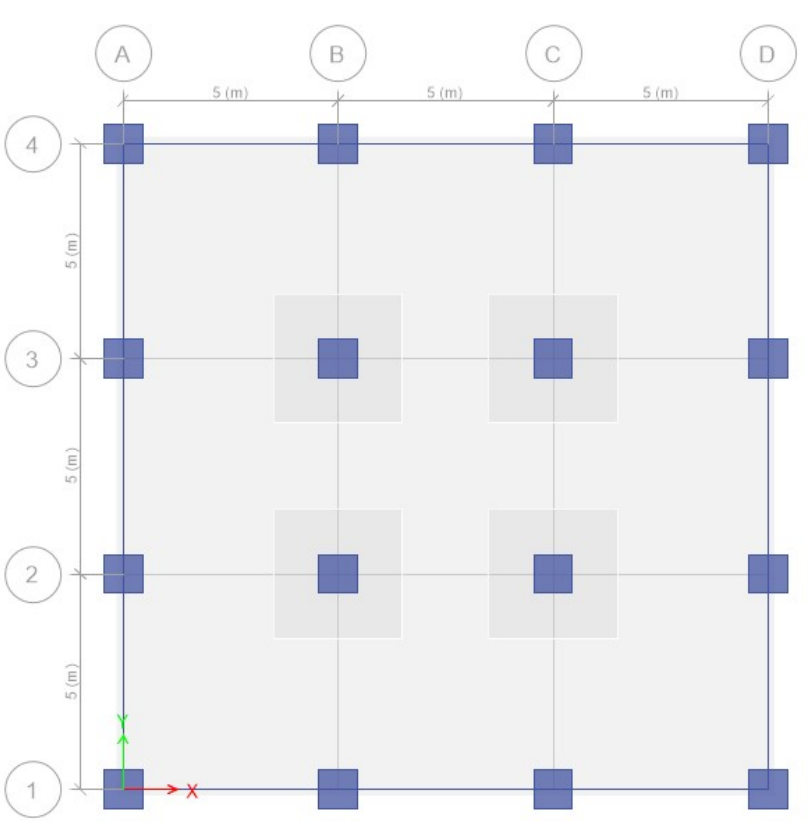

Fig 1: Plan

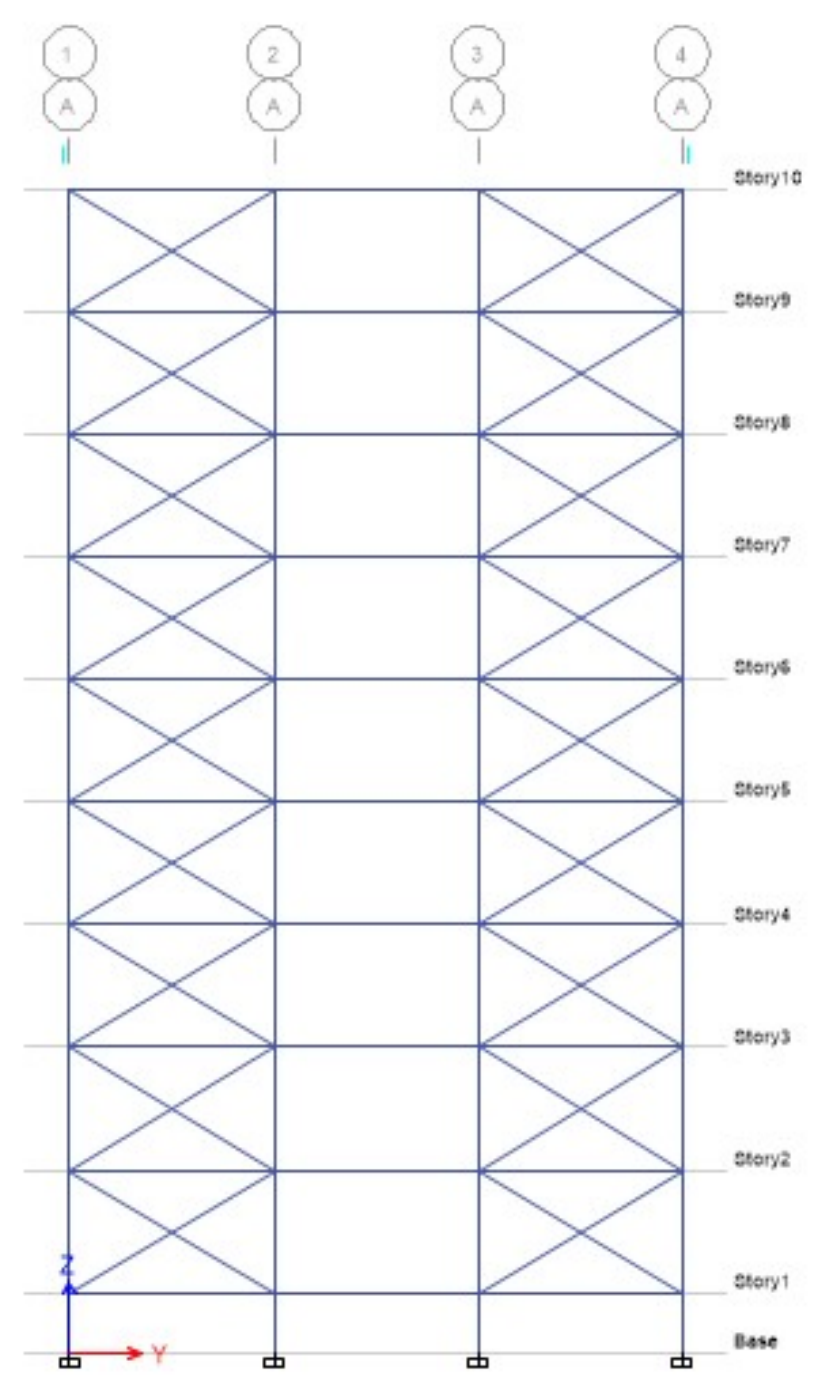

Fig 2: Elevation of $\mathrm{X}$ bracing 


\begin{tabular}{|c|c|}
\hline Layout of plan & - $\quad$ 4bays x 4bays \\
\hline Spacing of each bay & - $5 \mathrm{~m}$ \\
\hline Support conditions & - $\quad$ Fixed \\
\hline Height of each storey & - $3 \mathrm{~m}$ \\
\hline Grade of concrete & - $\quad 40 \mathrm{Mpa}$ \\
\hline Grade of reinforced steel & - $\quad$ Fe500 \\
\hline Structural steel considered & - $\quad$ ISMB 450 \\
\hline Thickness of main wall & - $200 \mathrm{~mm}$ \\
\hline Column size & - $\quad 900 \mathrm{mmx} 900 \mathrm{~mm}$ \\
\hline Beam size & - $\quad 500 \mathrm{mmx} 500 \mathrm{~mm}$ \\
\hline Flat Slab thickness & - $125 \mathrm{~mm}$ \\
\hline Floor finish load & - $1 \mathrm{kN} / \mathrm{m}^{2}$ \\
\hline Live load & - $\quad 3 \mathrm{kN} / \mathrm{m}^{2}$ \\
\hline Seismic Zone & - $\quad \mathrm{IV}(\mathrm{Z}=0.24)$ \\
\hline Soil type & - $\quad$ II \\
\hline Importance factor & $\begin{array}{lll}\cdot 1 & 1\end{array}$ \\
\hline Response reduction factor & - 3 \\
\hline Damping ratio & - $5 \%$. \\
\hline
\end{tabular}

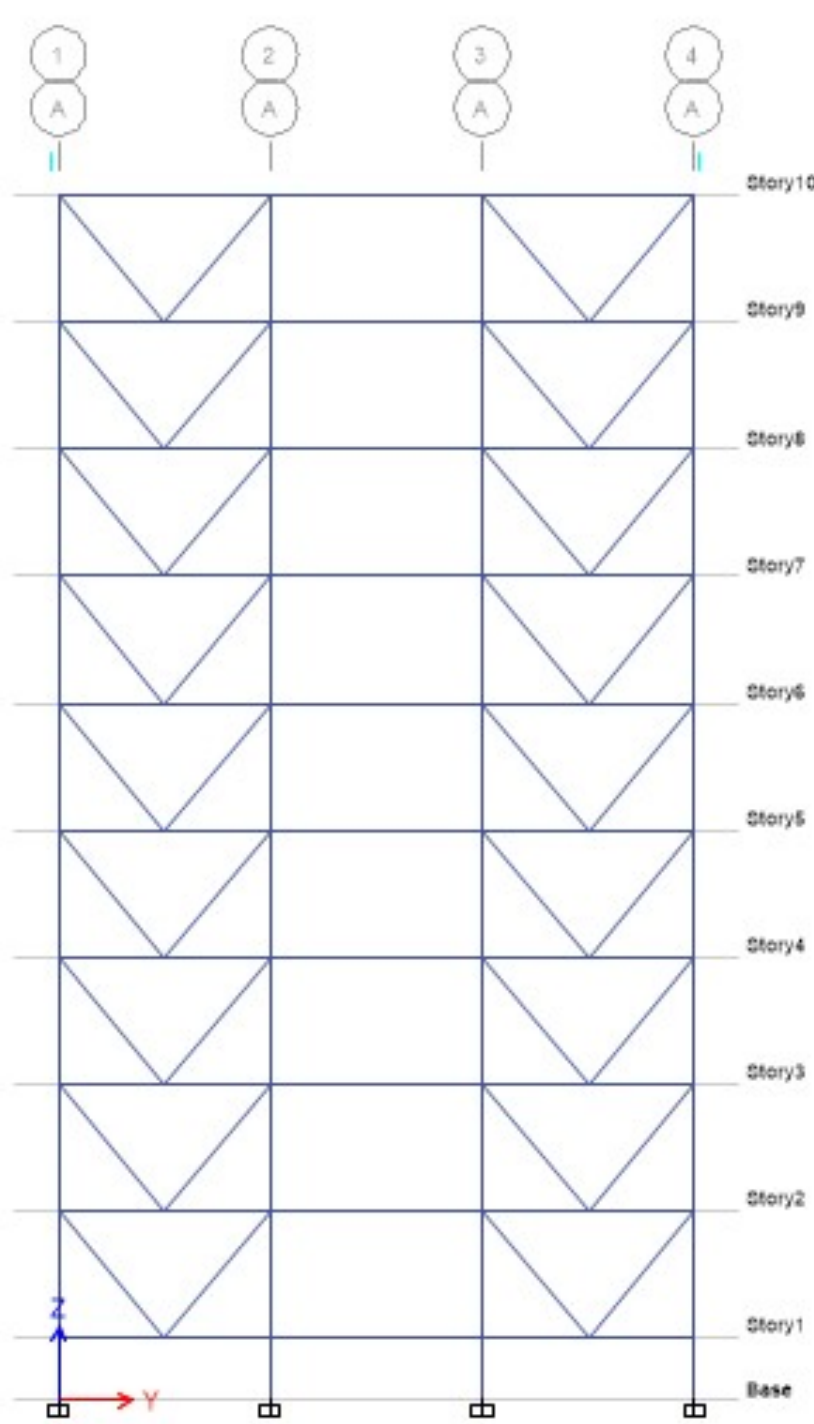

Fig 3: Elevation of V bracing.

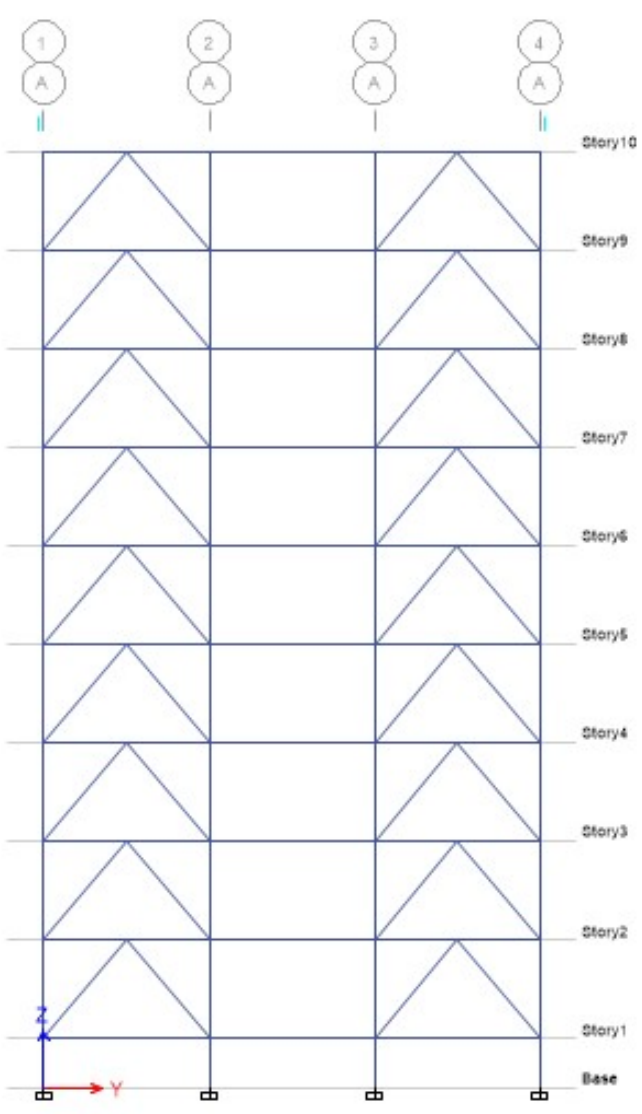

Fig 4: Elevation of inverted V bracing

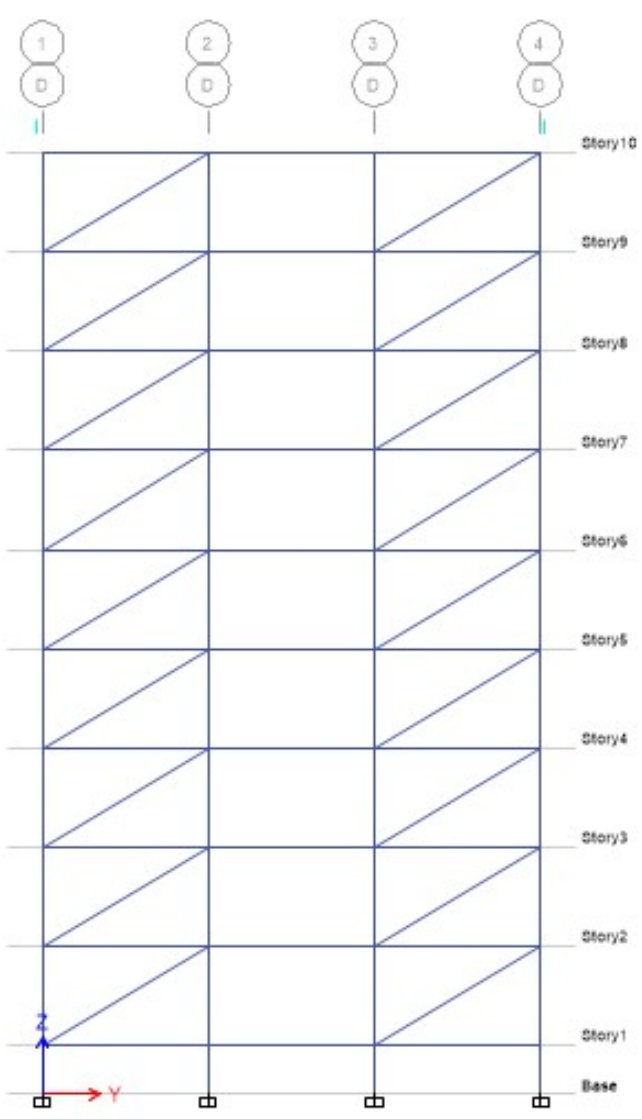

Fig 5: Elevation of diagonal bracing 


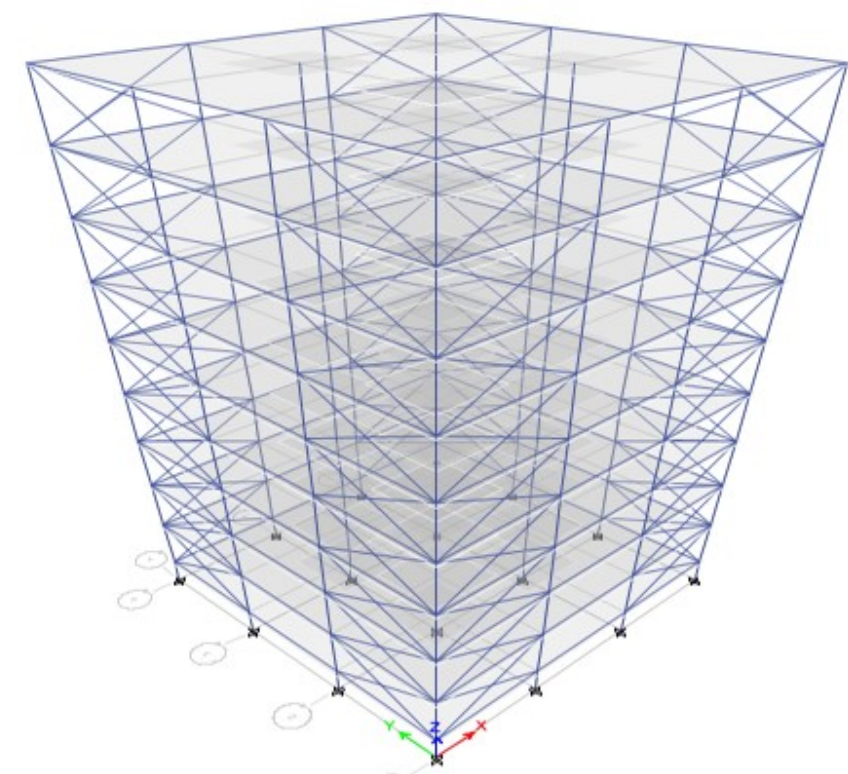

Fig 6: Arrangement of bracing system.

\section{RESULTS AND DISCUSSION}

The present work took place to compare the dynamic response of buildings with bracings. Totally 15 models/structures are taken for Dynamic analysis which includes Response Spectrum method. Code used is IS-1893 (part-I):2002 for Response Spectrum method from which storey shear, storey drift, slab stresses and storey displacement results for seismic zone-IV are obtained.

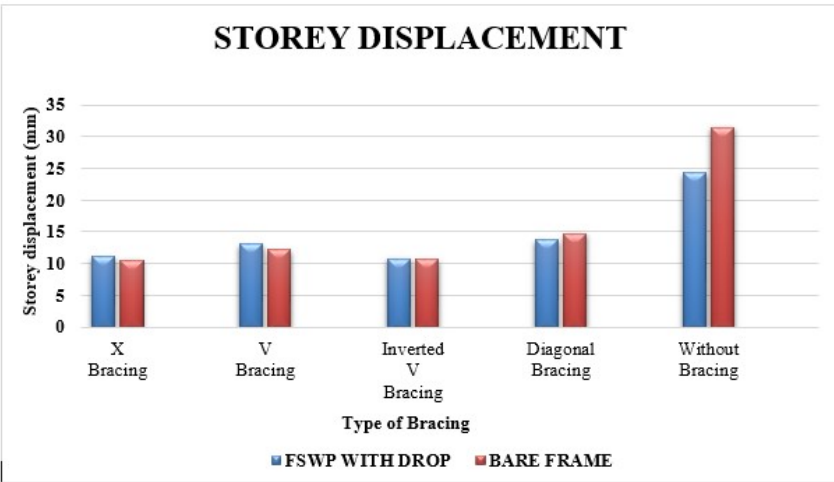

Chart -1: Storey Displacement v/s type of bracingalong Xdirection

\section{STOREY DISPLACEMENT}

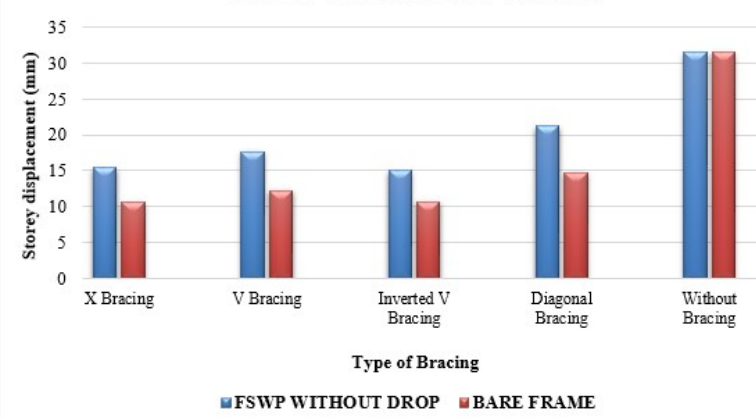

Chart -2: Storey Displacement v/s type of bracing along Xdirection
The chart 1,2 shows the variation of maximum storey displacement $\mathrm{v} / \mathrm{s}$ type of bracing along $\mathrm{X}$ direction and the comparison of Flat slab with perimeter beam (FSWP) with and without drop panel and $\mathrm{RC}$ bare frame. As seen above the lateral displacement is minimum for inverted $\mathrm{V}$ and $\mathrm{X}$ bracings. It is observed that without bracing and flat slab without drop panel structure has more displacement value. The percentage reduction of displacement is

Table 1: Percentage reduction of displacement ( $\mathrm{mm}$ ) of $X$ bracing with drop panel

\begin{tabular}{|l|l|l|l|}
\hline \multirow{2}{*}{$\begin{array}{l}\text { No.of } \\
\text { stories }\end{array}$} & \multicolumn{2}{|l|}{ Seismic Loads } & \multirow{2}{*}{ \%Reduction } \\
\cline { 2 - 3 } & $\begin{array}{l}\text { Without } \\
\text { bracing }\end{array}$ & $\begin{array}{l}\text { X } \\
\text { Bracing(with } \\
\text { drop panel) }\end{array}$ & \\
\hline $7^{\text {th }}$ storey & 22.83 & 7.56 & 66.86 \\
\hline $8^{\text {th }}$ storey & 26.19 & 8.84 & 66.23 \\
\hline $9^{\text {th }}$ storey & 29.04 & 10.02 & 65.59 \\
\hline $10^{\text {th }}$ storey & 31.48 & 11.08 & 64.78 \\
\hline
\end{tabular}

Table 2: Percentage reduction of displacement (mm) of $\mathrm{X}$ bracing without drop panel.

\begin{tabular}{|c|c|c|c|}
\hline \multirow[b]{2}{*}{$\begin{array}{l}\text { No.of } \\
\text { stories }\end{array}$} & \multicolumn{2}{|c|}{ Seismic Loads } & \multirow[b]{2}{*}{ \%Reduction } \\
\hline & $\begin{array}{l}\text { Without } \\
\text { bracing }\end{array}$ & $\begin{array}{l}\text { XBracing(without } \\
\text { drop panel) }\end{array}$ & \\
\hline $7^{\text {th }}$ storey & 31.93 & 10.59 & 66.85 \\
\hline $8^{\text {th }}$ storey & 36.52 & 12.37 & 66.12 \\
\hline $9^{\text {th }}$ storey & 40.38 & 14.04 & 65.32 \\
\hline $10^{\text {th }}$ storey & 31.48 & 15.47 & 50.84 \\
\hline
\end{tabular}

Table 3: Percentage reduction of displacement $(\mathrm{mm})$ of Inverted V bracing with drop panel.

\begin{tabular}{|c|c|c|c|}
\hline \multirow[b]{2}{*}{$\begin{array}{l}\text { No.of } \\
\text { stories }\end{array}$} & \multicolumn{2}{|c|}{ Seismic Loads } & \multirow[b]{2}{*}{ \%Reduction } \\
\hline & $\begin{array}{l}\text { Without } \\
\text { bracing }\end{array}$ & $\begin{array}{l}\text { Inverted V } \\
\text { Bracing(with } \\
\text { drop panel) }\end{array}$ & \\
\hline $7^{\text {th }}$ storey & 22.83 & 7.45 & 67.36 \\
\hline $8^{\text {th }}$ storey & 26.19 & 8.67 & 66.91 \\
\hline $9^{\text {th }}$ storey & 29.04 & 9.77 & 66.35 \\
\hline $10^{\text {th }}$ storey & 31.48 & 10.75 & 65.85 \\
\hline
\end{tabular}

Table 4: Percentage reduction of displacement ( $\mathrm{mm})$ of Inverted $\mathrm{V}$ bracing without drop panel

\begin{tabular}{|c|c|c|c|}
\hline \multirow[b]{2}{*}{$\begin{array}{l}\text { No.of } \\
\text { stories }\end{array}$} & \multicolumn{2}{|c|}{ Seismic Loads } & \multirow[b]{2}{*}{ \%Reduction } \\
\hline & $\begin{array}{l}\text { Without } \\
\text { bracing }\end{array}$ & $\begin{array}{l}\text { Inverted V } \\
\text { Bracing(without } \\
\text { drop panel) }\end{array}$ & \\
\hline $7^{\text {th }}$ storey & 31.93 & 10.42 & 67.36 \\
\hline $8^{\text {th }}$ storey & 36.52 & 12.12 & 66.81 \\
\hline $9^{\text {th }}$ storey & 31.48 & 13.66 & 66.17 \\
\hline $10^{\text {th }}$ storey & 31.48 & 15.02 & 52.28 \\
\hline
\end{tabular}




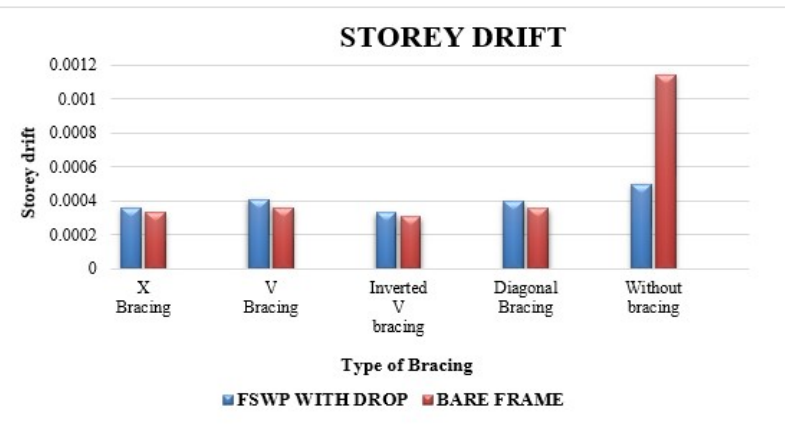

Chart -3: Storey Drift v/s type of bracing along X-direction

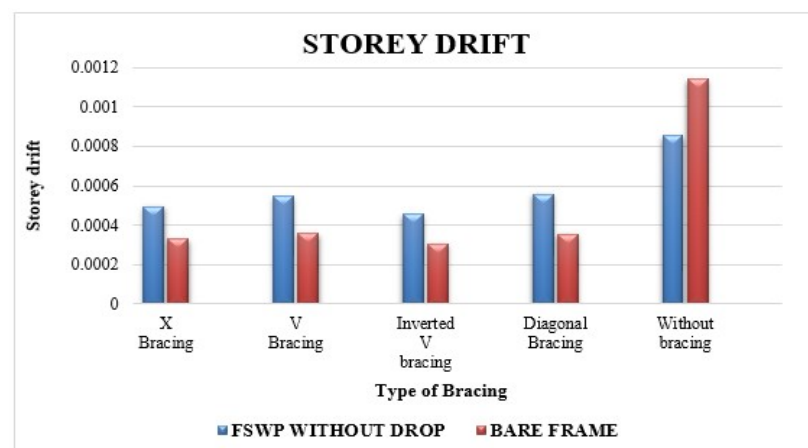

Chart -4: Storey Drift v/s type of bracing along X-direction

The Chart- 3,4 shows the variation of maximum storey drift $\mathrm{v} / \mathrm{s}$ type of bracing along $\mathrm{X}$ direction and the comparison of Flat slab with perimeter beam (FSWP) with and without drop panel and RC bare frame. As seen above the drift is minimum for inverted $\mathrm{V}$ and $\mathrm{X}$ bracings. It is observed that without bracing and flat slab without drop panel structure has more drift value.

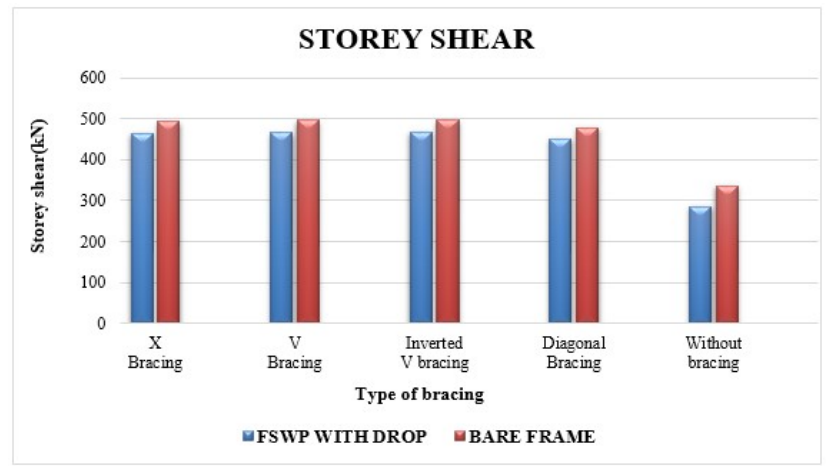

Chart -5: Base Shear v/s type of bracing along X-direction

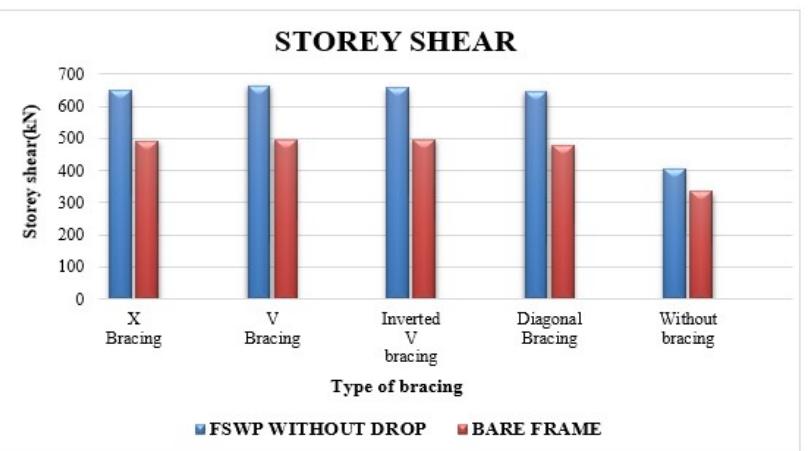

Chart -6: Base Shear v/s type of bracing along X-direction
The chart 5,6 shows the variation of maximum storey shear $\mathrm{v} / \mathrm{s}$ type of bracing along $\mathrm{X}$ direction and the comparison of Flat slab with perimeter beam (FSWP) with and without drop panel and RC bare frame. As seen above the base shear is maximum for $\mathrm{V}$ and inverted $\mathrm{V}$ bracing. It is observed that without bracing and flat slab without drop panel structure has lessbase shear value.

\section{CONCLUSION}

- Steel bracing system provides the economical and efficient measures for RC multi-storey structures in high seismic regions.

- One of the advantageous concepts which can also be used to retrofit the existing structures is the usage of steel bracing.

- The percentage reduction of storey displacement in the structure is tabulated by comparing $\mathrm{X}$ and Inverted $\mathrm{V}$ bracing structure with bare frame structure.

- In this study, as compared to $\mathrm{V}$ and diagonal braced frame the inverted $\mathrm{V}$ and $\mathrm{X}$ braced frame got minimum displacements and storey drift value.

- Steel bracing increases the storey shear of the structure. Here the $\mathrm{V}$ bracing and Inverted $\mathrm{V}$ storey shear is more in the structure. This will be the estimate of maximum expected lateral force that a building can resist.

- The arrangements of bracings made at the corners of the structures has considerable effect on seismic performance.

- Providing the steel bracings and drop panels gives less slab stress on structure compared to RC bare frame.

- Hence it is concluded that the use of steel bracing with flat slab in construction resists the lateral forces.

\section{REFERENCES}

[1]. AnujaWalvekar, H.S.Jadhav"Parametric Study of Flat Slab Building with and Without Shear Wall to Seismic Performance" Volume: 04, Apr-2015.

[2]. B.Anjaneyulu, K Jaya Prakash"Analysis and Design of Flat Slab by Using Etabs Software"International Journal of Science Engineering and Advance Technology, Vol. 4 February-2016.

[3]. EmaCOELHO, Paulo CANDEIAS, Giorgios ANAMATEROS"Assessment of the Seismic Behaviour of Rc Flat Slab Building Structures". 13th World Conference on Earthquake Engineering Vancouver, B.C., Canada August 1-6, 2004.

[4]. Mohammed Idrees Khan, Mr.KhalidNayaz Khan."Seismic Analysis of Steel Frame with Bracings using Pushover Analysis" International Journal of Advanced Technology in Engineering and Science Volume No.02, July 2014.

[5]. Mohana H.S, Kavan M.R "Comparative Study of Flat Slab and Conventional Slab Structure Using ETABS for Different Earthquake Zones of India" International Research Journal of Engineering and Technology Volume: 02 June2015

[6]. Pradip S. Lande, Aniket B. Raut "Seismic Behaviour of Flat Slab Systems" Journal of Civil Engineering and 
Environmental Technology Volume 2, Number 10; AprilJune, 2015.

[7]. Prof.BhosleAshwiniTanaji, Prof. Shaikh A. N “Analysis of Reinforced Concrete Building with Different Arrangement of Concrete and Steel Bracing system". IOSR Journal of Mechanical and Civil Engineering Volume 12, (Sep. - Oct. 2015)

[8]. R.P.Apostolska, G.S.Necevska-vetanovska, J.P.Cvetanovska and N. Mircic "Seismic Performance of Flat-Slab BuildingStructural Systems". The $14^{\text {th }}$ world Conference on Earthquake Engineering October 12-17, 2008, Beijing, China

[9]. R.S.More, V. S. Sawant, Y. R. Suryawanshi "Analytical Study of Different Types of Flat Slab Subjected to Dynamic Loading" International Journal of Science and Research Volume 4, July 2015

[10]. Shachindra Kumar Chadhar,

Dr.AbhaySharma"Seismic Behavior ofRc Building Frame with Steel Bracing System using Various Arrangements" International Research Journal of Engineering and Technology (IRJET) e-ISSN: 2395 -0056 Volume: 02 Issue: 05 | Aug-2015.

[11]. Umesh.R.Biradar, ShivarajMangalgi "Seismic Response of Reinforced Concrete Structure by using Different Bracing Systems" International Journal of Research in Engineering and Technology, Volume: 03 Sep2014

[12]. Viswanath K.G, Prakash K.B, Anant Desai "Seismic Analysis of Steel Braced Reinforced Concrete Frames" International Journal of Civil and Structural Engineering Volume 1, No 1, 2010

\section{BIOGRAPHIES}

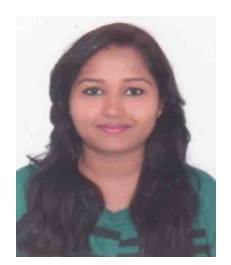

Dakshayani S, MTech Student, Department of Civil Engineering, Global Academy of Technology, Bengaluru 560098

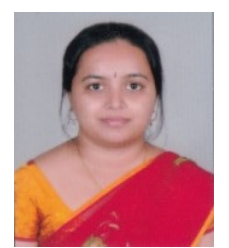

Chaithra N, Asst. Professor, Department of Civil Engineering, Global Academy of Technology, Bengaluru -560098 